\title{
Sexual behaviour of women with human papillomavirus (HPV) lesions of the uterine cervix
}

\author{
K SYRJÄNEN,* M VÄYRYNEN,† O CASTRÉN,† M YLISKOSKI,† \\ R MÄNTYJÄRVI, $\neq$ S PYRHÖNEN,§ AND S SAARIKOSKI†
}

From the *Department of Pathology, University of Kuopio, the +Department of Gynaecology and Obstetrics, Kuopio University Central Hospital, the $¥$ Department of Clinical Microbiology, University of Kuopio, Kuopio, and the §Department of Virology, University of Helsinki, Helsinki, Finland

SUMMARY To analyse the epidemiological aspects contributing to the transmission of human papillomavirus (HPV) lesions (flat, inverted, and papillomatous condylomas) of the uterine cervix, we recorded the sexual behaviour of 146 women who consecutively attended the department of obstetrics and gynaecology of Kuopio University Central Hospital with a cervical HPV lesion (with or without concomitant cervical intraepithelial neoplasia (CIN)). Similar data were collected from an age matched group of women with no signs of gynaecological infection. The sexual habits of the women infected with HPV differed from those of healthy controls in most aspects studied, including an earlier onset of sexual activity $(p<0 \cdot 05)$, lower number of deliveries $(p<0.05)$, less regular use of contraceptive measures $(p<0 \cdot 05)$, and use of the condom instead of intrauterine contraceptive device (IUCD) $(p<0 \cdot 0001)$. They also differed from controls in giving histories of more frequent episodes of: CIN $(p<0 \cdot 005)$, abnormal Pap (Papanicolaou) smears $(p<0.0001)$, sexually transmitted disease (STD) $(p<0.05)$, and genital warts $(p<0.001)$. Furthermore, they had more multiple sexual partnerships (both past and current) than the controls ( $<<0.0001$ and 0.005 respectively), they had not established permanent partnerships as often as the controls $(p<0.001)$, and they had a higher frequency of casual relationships $(p<0.0001)$. In addition, their own and their partners' sexual hygiene was poorer than in the control subjects ( $p<0.05$ and 0.001 respectively). The results show the dramatic influence of sexual behaviour on the transmission of cervical HPV lesions, which are known to be intimately associated with CIN in many cases.

\section{Introduction}

For some time sexual promiscuity and early onset of sexual activity have been considered to be responsible for the observed increase of cervical intraepithelial neoplasia (CIN) in very young girls. ${ }^{1-8} \mathrm{CIN}$ in turn is known to proceed to an invasive carcinoma within varying periods of time. ${ }^{10}$ Not surprisingly many authors are convinced that carcinoma of the uterine cervix is a sexually transmitted disease (STD), probably caused by a virus. ${ }^{711-16}$ This hypothesis has recently gained support from reports linking cervical and penile cancer and emphasising the role of high risk men in the aetiology of cervical cancer. ${ }^{17-23}$

Since the 1960s, the transmissible agent blamed for

Address for reprints: Dr K Syrjănen, Senior Lecturer, Department of Pathology, University of Kuopio, P O Box 6, SF-70211 Kuopio 21 , Finland

Accepted for publication 30 November 1983 the development of cervical cancer has been herpes simplex virus (HSV). 671213 It was not until 1976 that the possible role of human papillomavirus (HPV) was explored..$^{24}{ }^{25}$ Since then, this theory has gained substantial support from the observations on the new types of HPV lesions (flat and inverted condylomas), which have been reported to be closely associated with CIN and even with invasive cervical carcinomas. ${ }^{26-32}$ At the moment, HPV seems to be the agent most likely to cause uterine cervical carcinoma. ${ }^{25-35}$

The natural history of the classic papillomatous genital wart (condyloma acuminatum) as an STD induced by HPV is well recognised..$^{25}{ }^{34-38}$ The peak incidence of condyloma acuminatum coincides with the period of maximum sexual activity. ${ }^{36-38}$ Little is known about the natural history of the newly described flat and endophytic condylomas ${ }^{38}$ shown to be intimately associated with CIN.24 26-30 32 
As a part of a long term follow up study of women with cervical HPV lesions that is currently in progress in our clinic, we report on the sexual habits of such women to provide evidence of the influence of sexual behaviour on the development and spread of this increasingly common infection.

\section{Materials and methods}

We studied the first 146 consecutive women included in our prospective follow up study of women with an HPV (flat, inverted, or papillomatous) lesion of the uterine cervix. The present study was set up to assess the natural history (and all factors influencing it) of these HPV lesions and concomitant CIN changes that are unaffected by any kind of treatment. During this study, the women attended the outpatient department of obstetrics and gynaecology, Kuopio University Central Hospital, at six month intervals. At each visit the patients underwent colposcopy and either a biopsy or a Pap (Papanicolaou) smear. In addition, material was taken from the cervix for microbiological examination, and a blood sample was collected for immunological analysis.

The patients had been selected for the prospective follow up study on the basis of a Pap smear suggesting HPV. ${ }^{24} 30$ On their first attendance at the hospital, the diagnosis was confirmed by colposcopy and biopsy examination, using the criteria described previously. ${ }^{26-29} 32$ All the patients included in the present study had a definite HPV (flat, inverted, or papillomatous) lesion of the uterine cervix, either with or without concomitant CIN.

During their first clinic visit, all the women were asked to answer an extensive questionnaire to give data of possible epidemiological relevance to their HPV infection and its transmission, which included their previous gynaecological and obstetric history, their medical history, and any history of STD. Data

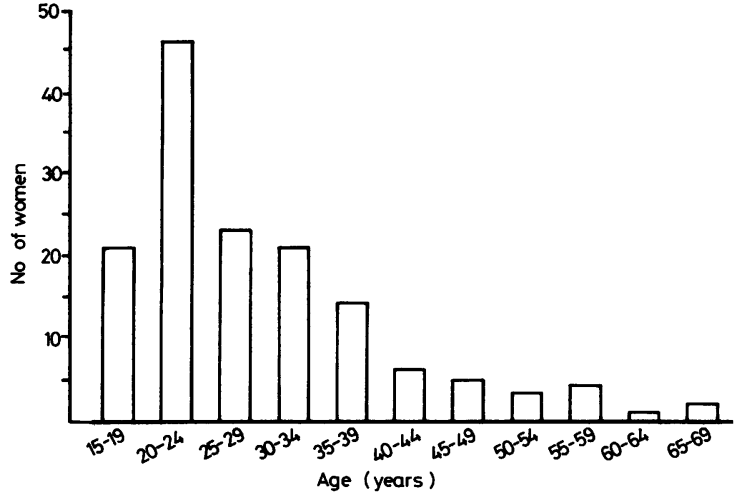

FIGURE Age distribution of the women studied in two age matched groups.

concerning their sexual partners and technical aspects of their sexual intercourse were also recorded in detail. To facilitate the acceptability of this inquiry the questionnaire was completed anonymously.

To extract the data pertinent to the epidemiology of HPV infection and its transmission, the same questions were presented to an age matched series of healthy women without any signs of HPV infection of the uterine cervix. This was accomplished by mailing the questionnaire to a randomly selected series of women who had normal Pap smears. (The Pap smears of the patients with HPV and the controls were examined by the pathologist at the laboratory of pathology, Finnish Cancer Society, Kuopio). From this series, every patient with HPV was matched by age with a control in an otherwise completely random manner. The present report is based on questionnaires answered by two age matched groups of 146 women, one group with cervical HPV infection and the other without any signs of a genital infection. The age distribution of both groups of women is shown in the figure.

TABLE I Comparison of gynaecological and obstetric histories of controls and women with HPV infections

\begin{tabular}{|c|c|c|c|}
\hline & $\begin{array}{l}\text { Controls } \\
(n=146)\end{array}$ & $\begin{array}{l}\text { Patients with } \\
\text { condylomas } \\
(n=146)\end{array}$ & $\begin{array}{l}\text { Signifi- } \\
\text { cance }\end{array}$ \\
\hline $\begin{array}{l}\text { Mean (SD) age (years) } \\
\text { Mean (SD) age at menarche (years) } \\
\text { No menstruating regularly } \\
\text { No menstruating irregularly } \\
\text { Mean (SD) No of pregnancies } \\
\text { Mean (SD) No of deliveries } \\
\text { Mean (SD) No of miscarriages } \\
\text { Mean (SD) No of abortions } \\
\text { Mean (SD) age at first coitus (years) } \\
\text { Mean (SD) years of active sexual life } \\
\text { No regularly using contraception: } \\
\text { Oral contraceptive } \\
\text { Condom } \\
\text { Intrauterine contraceptive device } \\
\text { Sterilised } \\
\text { Other contraceptive }\end{array}$ & $\begin{array}{cc}29 \cdot 1 & (10 \cdot 7) \\
13 \cdot 3 & (1 \cdot 3) \\
93 & \\
53 & \\
2 \cdot 53 & (1 \cdot 49) \\
2 \cdot 09 & (1 \cdot 32) \\
0 \cdot 19 & (0 \cdot 49) \\
0 \cdot 24 & (0 \cdot 48) \\
18 \cdot 1 & (2 \cdot 9) \\
10 \cdot 9 & (9 \cdot 0) \\
119 & \\
51 & \\
17 & \\
55 & \\
3 & \\
2 & \\
& \end{array}$ & $\begin{array}{cl}28 \cdot 7 & (10 \cdot 3) \\
13 \cdot 2 & (1 \cdot 4) \\
88 & \\
58 & \\
2 \cdot 27 & (1 \cdot 41) \\
1 \cdot 68 & (1 \cdot 29) \\
0 \cdot 18 & (0 \cdot 44) \\
0 \cdot 36 & (0 \cdot 62) \\
17 \cdot 5 & (2 \cdot 6) \\
11 \cdot 5 & (9 \cdot 9) \\
85 & \\
42 & \\
23 & \\
27 & \\
4 & \\
4 & \\
\end{array}$ & $\begin{array}{l}\text { NS } \\
\text { NS } \\
\text { NS } \\
\text { NS } \\
\text { NS } \\
0 \cdot 05 \\
\text { NS } \\
\text { NS } \\
0 \cdot 05 \\
\text { NS } \\
0 \cdot 05 \\
\text { NS } \\
0 \cdot 05 \\
0 \cdot 001 \\
\text { NS } \\
\text { NS }\end{array}$ \\
\hline
\end{tabular}


TABLE II Medical histories of controls and women with HPV infections

\begin{tabular}{|c|c|c|c|}
\hline & $\begin{array}{l}\text { Controls } \\
(n=146)\end{array}$ & $\begin{array}{l}\text { Patients with } \\
\text { condylomas } \\
(n=146)\end{array}$ & $\begin{array}{l}\text { Signifi- } \\
\text { cance }\end{array}$ \\
\hline Previous cervical intraepithelial neoplasia & 0 & 7 & 0.005 \\
\hline During the past year & 0 & 3 & NS \\
\hline $1-2$ years ago & 0 & 3 & NS \\
\hline 2-4 years ago & 0 & 1 & NS \\
\hline Regular cervical cytological examination & 78 & 75 & NS \\
\hline \multicolumn{4}{|l|}{ Date of last Pap smear } \\
\hline First smear & 12 & 5 & NS \\
\hline During the past year & 35 & 59 & 0.005 \\
\hline $1-2$ years ago & 50 & 38 & NS \\
\hline $2-4$ years ago & 16 & 18 & NS \\
\hline More than 5 years ago & 3 & 6 & NS \\
\hline No data & 30 & 20 & \\
\hline Last Pap smear normal & 111 & 61 & 0.0001 \\
\hline Previous radiotherapy & 0 & 0 & NS \\
\hline \multicolumn{4}{|l|}{ Current treatment } \\
\hline Insulin & 0 & 1 & NS \\
\hline Oral hypoglycaemic agents & 1 & 0 & NS \\
\hline Steroids & 5 & 5 & NS \\
\hline Other immunosuppressive agents & 0 & 1 & NS \\
\hline
\end{tabular}

For the statistical calculations, Student's $t$ test and the $\chi^{2}$ test were used.

\section{Results}

Table I gives a summary of the gynaecological and obstetric history of the patients with HPV and the controls. The two groups differed from each other in the mean number of deliveries $(p<0 \cdot 05)$, the mean age of first coitus $(p<0 \cdot 05)$, and the regularity and type of contraception used. The women in the control group used an intrauterine contraceptive device (IUCD) more frequently than those with HPV $(p<0.001)$ and a condom less frequently $(p<0.05)$.

Table II shows the medical history of the women in the two groups. Those with HPV were more likely to have had CIN, to have had a recent Pap smear, and to have had an abnormal Pap smear result at their most recent examination (excluding the one by which the patient was entered into the study). The two groups did not differ from each other in current treatment of illnesses unrelated to HPV.

Table III shows histories of STD in both groups. The women with HPV were more likely than the controls to have had STD $(p<0 \cdot 05)$, and significantly more frequently had had warts especially genital warts $(p<0 \cdot 001)$. The two groups did not differ in respect of a history of warts in their sexual partners.

Table IV summarises the sexual relationships of the women in the two groups, who behaved differently in most respects. These included changes of previous as well as current sexual partners, establishing a permanent (over four years' duration) relationship, the mean number of partners within the past two years, and the occurrence of casual relationships.

Table $\mathrm{V}$ shows the data concerning the sexual habits of the women. Those with HPV practised intercourse on more occasions but less regularly than the controls $(p<0 \cdot 05)$. Both groups were similar with

TABLE III Comparison of histories of sexually transmitted disease in controls and women with HPV infections

\begin{tabular}{lccc}
\hline & $\begin{array}{l}\text { Controls } \\
(n=146)\end{array}$ & $\begin{array}{l}\text { Patients with } \\
\text { condylomas } \\
(n=146)\end{array}$ & $\begin{array}{l}\text { Signifi- } \\
\text { cance }\end{array}$ \\
\hline Previous sexually transmitted diseases & 2 & 8 & $0 \cdot 05$ \\
$\quad$ Gonorrhoea & 1 & 7 & $0 \cdot 05$ \\
$\quad$ Chlamydia & 1 & 1 & NS \\
Syphilis & 0 & 0 & NS \\
Warts in sexual partners: & 9 & 17 & NS \\
Genitalia & 2 & 6 & NS \\
Mouth & 0 & 1 & NS \\
Hand & 7 & 10 & $0 \cdot 005$ \\
Previous warts in patient & 21 & 43 & $0 \cdot 001$ \\
Genitalia & 2 & 18 & NS \\
Mouth & 0 & 3 & NS \\
Skin & 20 & 27 & NS \\
Anus & 2 & 4 & \\
\hline
\end{tabular}




\begin{tabular}{|c|c|c|c|}
\hline & $\begin{array}{l}\text { Controls } \\
(n=146)\end{array}$ & $\begin{array}{l}\text { Patients with } \\
\text { condylomas } \\
(n=146)\end{array}$ & $\begin{array}{l}\text { Signifi- } \\
\text { cance }\end{array}$ \\
\hline Current sexual partner unchanged (during past 2 years) & 143 & 131 & 0.005 \\
\hline \multicolumn{4}{|l|}{ Current sexual partner since: } \\
\hline Less than 1 year ago & 18 & 33 & $0 \cdot 025$ \\
\hline $1-3$ years ago & 27 & 46 & $0 \cdot 01$ \\
\hline 4-6 years ago & 39 & 13 & 0.001 \\
\hline More than 6 years ago & 57 & 33 & 0.005 \\
\hline Previous sexual partner (excluding past 2 years) unchanged & 112 & 73 & 0.0001 \\
\hline \multicolumn{4}{|l|}{ Frequency of change of previous sexual partners: } \\
\hline Less than once a year & 15 & 20 & NS \\
\hline 1-3 partners a year & 12 & 34 & NS \\
\hline 4-6 partners a year & 5 & 11 & NS \\
\hline More than 6 partners a year & 1 & 7 & NS \\
\hline Mean (SD) No of sexual partners in past 2 years & $1 \cdot 31(1 \cdot 31)$ & $2 \cdot 22(2 \cdot 56)$ & 0.001 \\
\hline Casual sexual partners: & 5 & 26 & 0.0001 \\
\hline Foreign & 0 & 1 & NS \\
\hline Domestic & 5 & 25 & 0.0001 \\
\hline
\end{tabular}

regard to the types of intercourse practised, but took more care over their own and their partners' sexual hygiene.

\section{Discussion}

HPV comprises a heterogeneous group of viruses, with at least 25 different types being recognised at the moment. ${ }^{33-35}$ Each HPV type seems to have a predilection for a particular site of infection, genital warts being associated with HPV6 and HPV11. ${ }^{33}$ Flat and inverted HPV lesions of the uterine cervix, ${ }^{24}$ have been repeatedly connected with CIN, and HPV is currently regarded as a potential aetiological agent of cervical carcinoma. ${ }^{25-33} 35$ It is accepted that condyloma acuminatum (mostly due to HPV6) is an STD, its incidence coinciding with peaks of sexual activity and promiscuity. ${ }^{36-38}$ The age distribution of patients with flat and inverted condylomas paralle!s that of those with condyloma acuminatum, ${ }^{26-32}$ but so far the association of HPV with sexual promiscuity has been speculative. ${ }^{32} 38$ This sexual behaviour has also been blamed for the increased incidence of atypical Pap smears and CIN reported in young age groups..$^{1-8}$ There seem to be many similarities between the epidemiology of condyloma acuminatum and cervical cancer, which is regarded by many as an STD. ${ }^{71-16}$ Whether this epidemiological similarity also holds true of the flat and inverted condylomas was the main topic of the present study. That this could be the case is suggested by the recent findings of HPV16 and HPV18 deoxyribonucleic acid (DNA) in more than $80 \%$ of cervical carcinomas studied, thus creating the concept of high risk HPV types (16 and 18) and low-risk types (6 and 11). ${ }^{33}$

As has been repeatedly emphasised, the only way to assess the clinical behaviour of HPV lesions is to conduct a prospective follow up study. ${ }^{25} 27-293132$ As a

TABLE V Comparison of data on sexual habits of women with HPV and controls

\begin{tabular}{|c|c|c|c|}
\hline & $\begin{array}{l}\text { Controls } \\
(n=I 46)\end{array}$ & $\begin{array}{l}\text { Patients with } \\
\text { condylomas } \\
(n=146)\end{array}$ & $\begin{array}{l}\text { Signifi- } \\
\text { cance }\end{array}$ \\
\hline Regular sexual intercourse & 79 & 55 & 0.005 \\
\hline Mean (SD) frequency of intercourse/week & $2 \cdot 20(1 \cdot 43)$ & $2 \cdot 63(2 \cdot 01)$ & 0.05 \\
\hline \multicolumn{4}{|l|}{ Type of sex practised: } \\
\hline Cunnilingus & 77 & 77 & NS \\
\hline $\begin{array}{l}\text { Fellatio } \\
\text { Sun }\end{array}$ & 76 & 86 & NS \\
\hline Anal & 13 & 16 & NS \\
\hline \multicolumn{4}{|l|}{ Above type of sex practised: } \\
\hline Regularly & 23 & 17 & NS \\
\hline Frequently & 12 & 20 & NS \\
\hline Seldom & 46 & 49 & NS \\
\hline Not specified & 7 & 7 & NS \\
\hline No data & 6 & 5 & NS \\
\hline \multicolumn{4}{|l|}{ Personal hygiene before intercourse: } \\
\hline Good & 113 & 93 & 0.05 \\
\hline Poor & 28 & 43 & 0.05 \\
\hline \multicolumn{4}{|l|}{ Partners' personal hygiene before intercourse: } \\
\hline Regularly good & 86 & 44 & $0 \cdot 0001$ \\
\hline Occasionally good & 96 & 64 & 0.001 \\
\hline
\end{tabular}


part of such a study in our clinic, the sexual behaviour of these patients was recorded for the first time. As shown in the figure, the age distribution of the patients studied is identical with that of other reports. ${ }^{31}{ }^{32}$ Most of the cervical HPV lesions occurred in women under 30 (mean $28 \cdot 7$ ) years with peak incidence in the 20-24 year old group. This paralleled the earlier onset of sexual activity in such women $(p<0.05)($ table $I)$. The women in the control group had significantly more deliveries $(p<0.05)$ than the HPV patients despite having the same number of pregnancies. This was due to a greater number of abortions (table I), and seemed to reflect the more permissive sexual habits and less regular and permanent sexual relationships of the women with HPV. Contraceptive measures were less frequently used by women with HPV than by controls $(p<0 \cdot 05)$. Furthermore, the less frequent use of an IUCD but more of the condom reflects the different attitudes to contraception of these two groups of women (table I).

With regard to their medical histories, none of the women in the control group had had CIN, whereas seven of the HPV patients had $(p<0.005)$. This is consistent with previous suggestions that early onset of sexual activity and promiscuous sexual habits predispose to the development of CIN. ${ }^{1-8}$ This should encourage an increased demand for cervical cytology tests, ${ }^{39}$ as was shown in this study by the increased numbers of recent (within the last year) Pap smears in women with HPV (table II). Consistently with the above views, the latest Pap smear in this group of women was abnormal significantly more frequently $(p<0.0001)$ (table II) than in the controls. The failure to find any appreciable difference in previous and current treatment including immunosuppression, which is known to predispose to warts, ${ }^{40}$ suggests that immunosuppression is not a major factor contributing to the development of cervical HPV (table II).

As pointed out in the classic paper by Oriel, ${ }^{36}$ the onset of genital warts parallels that of gonorrhoea. This was also the case in this study (table III), and patients with HPV gave a history of gonorrhoea significantly more frequently than the control women. On the other hand, no direct correlation could be established between cervical HPV and a history of cutaneous warts (table III). This confirms the results of Oriel, who did not find any epidemiological evidence of a close relation between genital and skin warts, ${ }^{36}$ and it has been established recently that these two lesions are caused by completely different types of HPV. ${ }^{34} 3540$ The women with HPV were more likely to have been treated previously for genital warts than the controls $(p<0.001)$, which supports the theory that external genital warts are frequently accompanied or followed by lesions in the uterine cervix. ${ }^{25} 323738$ Women with external genital warts should therefore be screened for cervical lesions.

This study confirms the association of promiscuity with HPV and CIN (table IV). Women with HPV changed their sexual partners significantly more often than controls, and controls had established permanent (over four years' duration) sexual partnerships significantly more frequently than the patients with HPV (table IV). This is shown by the mean numbers of sexual partners within the past two years. Similarly, the numbers of casual sexual contacts were exceedingly low in the control group (only 3.4\%) compared with those of women with HPV $(17 \cdot 8 \%)$. These data agree with the current concepts that genital warts are sexually transmitted, being found in female contacts of men with genital warts. ${ }^{36-38}$ This now seems to be established for the flat and inverted HPV lesions, which outnumbered the classic papillomatous ones in this study. The present study did not, however, establish a direct relation between the genital warts (visible ones) of the sexual partners and current HPV lesions in the women (table III). This is probably due to the failure of the women to remember how many of their partners had genital warts. The other, and perhaps even more important, explanation is that we do not currently recognise a counterpart of the flat and inverted HPV lesions, which may well exist in men. This emphasises the validity of the concept of high risk men, ${ }^{22}$ and we would advocate the study of the male partners of women infected with HPV.

Data on sexual habits show some pronounced differences between the two groups of women (table V). Intercourse was more often regular in the control group (mostly married) than in women with HPV, although the frequency of intercourse was higher in the latter. The types of sexual intercourse practised did not vary between the two groups. This could indicate that, generally speaking, anal and oral sex is not as important a source of HPV infection as is conventional coitus. That promiscuous sexual behaviour frequently goes hand in hand with poor sexual hygiene is clearly demonstrated in the present survey (table V). Good personal hygiene was almost the rule in the control group, but not in patients with HPV. The same seems to be true of their partners' sexual hygiene. The reason most frequently reported by the women with HPV was the lack of appropriate facilities. This reflects their lower socioeconomic status and the nature of the places where they practised sexual acts.

Most of the above data are familiar from the extensive surveys on risk factors of cervical cancer, including early onset of sexual activity (age at first 
coitus), multiple partners, poor sexual hygiene, and low socioeconomic status. ${ }^{1-4}$ 6-8 11-14 These data are confirmed by those obtained in this study of women with cervical HPV with or without CIN. In most respects our results show that the sexual habits of healthy women without any signs of HPV infection are noticeably different from those with a cervical HPV lesion. These epidemiological data show the crucial influence of sexual behaviour on the transmission of all types (flat, inverted, or papillomatous) of cervical HPV lesions associated (by morphology, immunology, and molecular biology) with the development of CIN and cervical cancer. 26-29 31-35 This further emphasises the significance of HPV as a potential cause of cervical cancer, and justifies the concept of all women infected with HPV as high risk patients.

This study was supported in part by a research grant (07/014) from the Medical Research Council of the Academy of Finland, and in part by a research grant from the Finnish Cancer Society.

\section{References}

1. Andrews FJ, Linehan JJ, Melcher DH. Cervical cancer in younger women. Lancet 1978; ii:776-8.

2. Feldman MJ, Linzey EM, Srebnik E, Kent DR, Goldstein AI, Nelson M. Abnormal cervical cytology in the teen-ager: a continuing problem. Am J Obstet Gynecol 1976; 126:418-21.

3. Feldman MJ, Kent DR, Pennington RL. Intraepithelial neoplasia of the uterine cervix in the teenager. Cancer 1978; 41: 1405-8.

4. King JFW. Sexual activity as environmental cancer hazard. $N$ $Y$ State J Med 1980; 80: 1253-8.

5. Roddick JW. Gynecologic disease in young, sexually active women. Am J Obstet Gynecol 1976; 126:880-9.

6. Rotkin ID. Adolescent coitus and cervical cancer: associations of related events with increased risk. Cancer Res 1967;27:603-17.

7. Rotkin ID. A comparison review of key epidemiological studies in cervical cancer related to current searches for transmissible agents. Cancer Res 1973; 33:1353-1567.

8. Snyder RN, Ortiz. Y, Willie S, Cove JKJ. Dysplasia and carcinoma in situ of the uterine cervix: prevalence in very young women (under age 22). Am J Obstet Gynecol 1976; 124: 751-6.

9. Johnson LD, Nickerson RJ, Easterday CL, Stuart RS, Hertig AT. Epidemiologic evidence for the spectrum of change from dysplasia through carcinoma in situ to invasive cancer. Cancer 1968;22:901-14.

10. Richart RM, Barron BA. A follow-up study of patients with cervical dysplasia. Am J Obstet Gynecol 1969; 105:386-93.

11. Beral V. Cancer of the cervix: a sexually transmitted infection? Lancet 1974: i: 1037-40.

12. Kessler II. Human cervical cancer as a venereal disease. Cuncer Res 1976; 36: 783-91.

13. Kessler II. Venereal factors in human cervical cancer. Fvidence from marital clusters. Cancer 1977; 39:1912-9.

14. Meisels A, Bégin R, Schneider V. Dysplasias of uterine cervix. Epidemiological aspects: role of age at first coitus and use of oral contraceptives. Cancer 1977;40:3076-81.
15. Munoz N. Model systems for cervical cancer. Cancer Res 1976; 36: 792-3.

16. Richardson AC, Lyon JB. The effect of condom use on squamous cell cervical intraepithelial neoplasia. Am J Obstet Gynecol 1981; 140:909-13.

17. Cocks PS, Adib RS, Hunt KM. Concurrent carcinoma of penis and carcinoma-in situ of the cervix in a married couple. Case report. Br J Obstet Gynaecol 1982;89:408-9.

18. Goldberg HM, Pell-Ilderton R, Daw E, Saleh N. Concurren squamous cell carcinoma of the cervix and penis in a married couple. Br J Obstet Gynaecol 1979;86:585-6.

19. Graham S, Priore R, Graham M, Browne R, Burnett W, West D. Genital cancer in wives of penile cancer patients. Cancer 1979;44:1870-4.

20. Martinez I. Relationship of squamous cell carcinoma of the cervix uteri to squamous cell carcinoma of the penis among Puerto Rican women married to men with penile carcinoma. Cancer 1969;24:777-80.

21. Reddy CRRM, Rao TG, Venkatarathnam G, Kameswari VR Sashiprabha R, Raghavaiah NV. A study of 80 patients with penile carcinoma combined with cervical biopsy of their wives. Int Surg 1977;62:549-53.

22. Singer A, Reid BL, Coppleson M. A hypothesis: the role of a high-risk male in the etiology of cervical carcinoma. Am J Obstet Gynecol 1976; 126:110-5.

23. Smith PG, Kinlen LJ, White GC, Adelstein AM, Fox AJ. Mortality of wives of men dying with cancer of the penis. $\mathrm{Br} J$ Cancer 1980; 41:422-8.

24. Meisels A, Fortin R. Condylomatous lesions of the cervix and vagina. I. Cytologic patterns. Acta Cytol (Baltimore) 1976; 20:505-9.

25. zur Hausen $\mathrm{H}$. Human Papillomaviruses and their possible role in squamous cell carcinomas. Curr Top Microbiol Immunol 1977; 78: $1-30$

26. Syriämem KJ. Morphologic survey of the condylomatous lesions in dysplastic and neoplastic epithelium of the uterine cervix. Arch Gynaekol 1979;227:153-61.

27. Syrjänen KJ. Condylomatous lesions in dysplastic and neoplastic epithelium of the uterine cervix. Surg Gynecol Obstet 1980; 150:372-6.

28. Syrjanen KJ. Condylomatous epithelial changes in uterine cervix and their relationship to cervical carcinogenesis. Int $J$ Gynaecol Obstet 1980; 17:415-20.

29. Syrjanen KJ. Current views on the condylomatous lesions in uterine cervix and their possible relationship to cervical squamous cell carcinoma. Obstet Gynecol Surv 1980;35: 685-94.

30. Syrjănen KJ, Heinonen U-M, Kauraniemi T. Cytological evidence of the association of condylomatous lesions with the dysplastic and neoplastic changes in uterine cervix. Acta Cytol (Baltimore) 1981;25: 17-22.

31. Syrjänen KJ. Human Papillomavirus (HPV) lesions in association with cervical dysplasias and neoplasias. Obste Gynecol 1983;62:617-24.

32. Meisels A, Morin C. Human papillomavirus and cancer of the uterine cervix. Gynecol Oncol 1981;12:111-23.

33. Gissmann L, Dürst M, Ikenberg H. Presence of HPV DNA in human genital carcinomas. Proc Natl Acad Sci USA 1983;80: 3812-4

34. Howley P. The human papillomaviruses. Arch Pathol Lab Med 1982; 106: 429-32.

35. zur Hausen H, Gissmann L. Papillomaviruses. In: Klein G, ed. Viral Oncology. New York: Raven Press, 1980 433-45.

36. Oriel JD. Natural history of genital warts. $\mathrm{Br} J$ Vener Dis 1971; 47:1-13

37. Oriel JD. Genital warts. Sex Transm Dis 1977; 4:153-9.

38. Oriel JD. Genital warts. Sex Transm Dis 1981;8:326-9.

39. Fields C, Restivo RM, Brown MC. Experience in mass Papanicolaou screening and cytologic observations of teen-age girls. Am J Obstet Gynecol 1976;124:730-4.

40. Jablonska S, Orth G, Lutzner MA. Immunopathology of papillomavirus-induced tumors in different tissues. Springer Semin Immunopathol 1982;5:33-62. 